\title{
Evaluating the Ramifications of ESP Vocabulary Instruction through Facilitating Cognitive Processing
}

ISSN: 2311-8636 (Print)

ISSN: 2312-2021 (Online)

DOI prefix: 10.18034/ajhal

Licensed:

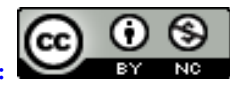

Source of Support: Nil

No Conflict of Interest: Declared

${ }^{*}$ Email for correspondence:

smkuo@must.edu.tw

\section{Shiue-mei Kuo}

Lecturer, Department of Applied Foreign Languages, Minghsin University of Science and Technology, Hsinchu 30401, TAIWAN

\section{ABSTRACT}

This study examines English for General Purposes' (EGP) words that take on specialized meanings in particular contexts. For English native speakers, it may be easy to differentiate between these according to context, but it is challenging for non-native speakers to build cognitive awareness of the divergence between English for Specific Purposes' (ESP) and EGP vocabulary usage. There are also conceptual metaphors within the ESP vocabulary that require cultural understanding or unequivocal definition guidance. Strengthening students' proficiency in navigating the demands of professional fields is the ultimate goal of practitioners. As has been observed during language practice, building ESP vocabulary is the imperative groundwork for non-native speakers to establish their language skills in their specialized occupational fields to enhance employability. This study undertakes a comparison of ESP vocabulary proficiency between an experimental and a control group. The experimental group is comprised of learners who undertook cognitive processing training through learning strategies in business English courses, in which vocabulary was presented to students in ways that aimed to facilitate cognitive processing of ESP vocabulary acquisition. The control group is comprised of learners who took English vocabulary courses adopting conventional approaches toward intensifying their vocabulary volume. The outcome indicates that the experimental group significantly outperforms the control group in ESP vocabulary proficiency level. Examining these two groups allows us to explore the extent of the enhancement rate of vocabulary learning provided by ESP cognitive strategies' training. Implications for future ESP reinforcement plans are also discussed in accordance with the findings.

Key Words: ESP vocabulary, contextual concept, ESP cognition, cognitive processing, learning strategy

\section{INTRODUCTION}

Globalization leads to stiff competition in job markets. English is the lingua franca for all countries to promote trade, commerce, marketing, banking, technology, and so on. English for specific purposes' communication plays a crucial role in English language learning, as it is one of the major goals toward gaining upward occupational opportunities. This study 
aims to evaluate the effects of the cognitive processing of ESP (with focal points in the fields of business and financial English) vocabulary learning.

\section{ESP Vocabulary}

Learning vocabulary is like laying bricks when building a house: learners and builders need to construct a solid foundation in order for the edifices to be concrete and useable. Nation (1990:4) points out that when practicing approaches to vocabulary learning, teachers need to consider three questions:

- What vocabulary do my learners need to know?

- How will they learn this vocabulary?

- How can I test to see what they need to know and what they now know? (Nation, 1990: 4)

This is especially pivotal in ESP instruction as English learners have specific purposes or goals to reach in order to enhance occupational achievement under circumstances of having limited time and energy available to learn. After learners have mastered thousands of EGP words, directing vocabulary learning to more specialized areas, based on the needs and aims of learners, is called for (Nation, 1990: 138). That is why most tertiary education, including colleges, universities, and language institutions, offer business English, financial English, or engineering English courses for students to enhance their job-seeking qualifications.

Harding (2007:53) points out the importance of vocabulary in ESP courses, partly because specific technical words are used to describe particular features of the specialty, and these technical meanings need to be acquired for the learner to function well within that specialty. Teaching English for Specific Purposes' (ESP) vocabulary requires some sub-skills: wordbuilding, deriving meaning from context, and understanding appropriate genre and register. This is an ongoing process. Harding (2007:67) also suggests ways of exploiting corpora, for instance, helping students to learn collocation and infer meaning from context by guiding them to use research sources for vocabulary work, such as dictionaries, Internet search engines, subject reference books, and other corpora (Harding, 2007:67-71).

Identifying ESP vocabulary within a particular context or metaphor that diverges from everyday usage is difficult. The EGP words with specialized meanings can be difficult for learners to acquire, as they are often new concepts or meanings that have been established in the lexicon in a particular way (Coxhead, 2013:115-116). For instance, appreciate in business purposes or ESP contexts means to increase in price or value, rather than to perceive something as valuable as in EGP; face-lift not only means performing cosmetic surgery on faces, but also an improvement in financial conditions in ESP; and peripheral means computer accessories in a computer science context, rather than something not in the direct line of sight in EGP. ESP is a fast-moving and critical field as technical meanings can change quickly. For non-native English speakers, differentiating meaning between EGP and ESP takes special training.

Dudley-Evans and St John (1998:82) discuss their concerns about ESP vocabulary, including semi-technical vocabulary in English for academic purposes (EAP) and core business vocabulary in English for business purposes (EBP). In doing so, they draw on Baker's (1988:92) definition of ESP as "vocabulary that has specialized and restricted meanings in certain disciplines and which may vary in meaning across disciplines."Table 1 distinguishes two types of ESP vocabulary (Dudley-Evans and St John, 1998: 83). 
Table I: Types of Vocabulary

\begin{tabular}{ll}
\hline Type of Vocabulary & Examples \\
\hline General vocabulary with a higher & academic: cycle, occur, factor, function \\
frequency in a specific field & evaluative adjective: relevant, important, \\
& interesting \\
& tourism: confirm, accept, advise, agree \\
& collocations: make a booking, launch a campaign \\
& bug in computer science \\
General English words with a & force, acceleration in physics \\
specific meaning in certain & stress and strain in mechanics and engineering \\
disciplines &
\end{tabular}

Source: Adapted from Dudley-Evans and St John (1998:83)

Distinguishing between vocabularies needed for comprehension and production is important. In comprehension, the most important method of learning new vocabulary is deducing the meaning from context and from the structure of the actual word. For production purposes, storage and retrieval are necessary processes (Dudley-Evans and St John, 1998:83).Dudley-Evans and St John's account of ESP instruction significantly informs this research. English-language instruction in non-native English speaking countries needs to make additional efforts to collect these types of vocabulary items for learners to study. This kind of teaching material is not yet prominent in Taiwan, leading us to explore pragmatic ESP vocabulary and conduct further evaluation of the efficacy of teaching it.

In the literature, ESP vocabulary has been referred to by different names from one study to another. Specific purposes are often included in these terms, including specialized business, financial, or technical terms. In essence, such terms usually refer to the vocabulary of a particular area of study or professional use. The word range is important in ESP; in other words, specialized words may have a narrow range of use within a specialized area in a professional discipline (Coxhead, 2013:115-116). Coxhead (2013:116) also mentions an incisive point, namely, that specialized words are not necessarily highly technical words that are not used in everyday language. Everyday words can often carry specific meaning in particular contexts. This study aims to explore these kinds of words, which are easily confused by nonnative English speakers, and to investigate the effectiveness of ESP courses with cognitive strategies, further developing an understanding of how best to teach ESP vocabulary.

There are innumerable EGP words that take on ESP meanings in specific contexts, creating many dictionaries of specialized meanings, including, for example, those related to business, finance, engineering, and medicine. It is impractical for English learners to comprehend words in all fields, but learners and practitioners may focus on a prospective field and intensify the vocabulary volume for that particular area. Table II shows example English words whose specific meanings must be understood by non-native speakers in the field of finance and business.

Table II: Examples of English Vocabulary for Business Purposes (EBP)

\begin{tabular}{|c|c|c|}
\hline Vocabulary & EGP Definition & ESP/EBP Definition \\
\hline account & $\begin{array}{l}\text { to think of someone or } \\
\text { something in a stated way, e.g., } \\
\text { there is no accounting for taste }\end{array}$ & $\begin{array}{l}\text { an agreement with a shop or business that } \\
\text { allows you to buy things and pay for them } \\
\text { later }\end{array}$ \\
\hline appreciate & $\begin{array}{l}\text { to recognize how good } \\
\text { someone or something is }\end{array}$ & to increase in price, value \\
\hline appropriate & $\begin{array}{l}\text { suitable or right for a particular } \\
\text { situation or occasion }\end{array}$ & $\begin{array}{l}\text { to take something for your own use, } \\
\text { usually without permission }\end{array}$ \\
\hline
\end{tabular}




\begin{tabular}{|c|c|c|}
\hline balance & $\begin{array}{l}\text { a state where things are of equal } \\
\text { weight or force; equilibrium }\end{array}$ & $\begin{array}{l}\text { the amount of money that you have in your } \\
\text { bank account }\end{array}$ \\
\hline bond & $\begin{array}{l}\text { a close connection joining two } \\
\text { or more people }\end{array}$ & $\begin{array}{l}\text { an official paper given by the government } \\
\text { or a company to show that you have lent } \\
\text { them money that they will pay back to you } \\
\text { at a particularinterest rate }\end{array}$ \\
\hline book & $\begin{array}{l}\text { a written text published or } \\
\text { printed on paper or in } \\
\text { electronic form }\end{array}$ & $\begin{array}{l}\text { books: the written records of money that a } \\
\text { business has spent or received }\end{array}$ \\
\hline capital & $\begin{array}{l}\text { a city that is the center of } \\
\text { government of a country or } \\
\text { smaller political area }\end{array}$ & $\begin{array}{l}\text { money and possessions used for producing } \\
\text { more wealth or for starting a new business }\end{array}$ \\
\hline draft & $\begin{array}{l}\text { a piece of writing or a plan that } \\
\text { is not yet in its finished form }\end{array}$ & $\begin{array}{l}\text { a written order for money to be paid by a } \\
\text { bank }\end{array}$ \\
\hline duties & $\begin{array}{l}\text { something that you have to do } \\
\text { as your job }\end{array}$ & a tax you pay to the government \\
\hline equity & $\begin{array}{l}\text { when everyone is treated fairly } \\
\text { and equally }\end{array}$ & $\begin{array}{l}\text { the value of a property after you have paid } \\
\text { a mortgage or other charges relating to it }\end{array}$ \\
\hline float & $\begin{array}{l}\text { to stay on the surface of a liquid } \\
\text { and not sink }\end{array}$ & $\begin{array}{l}\text { to start selling shares in a business or } \\
\text { company for the first time }\end{array}$ \\
\hline turnover & $\begin{array}{l}\text { the rate at which employees } \\
\text { leave a company and are } \\
\text { replaced by new people }\end{array}$ & $\begin{array}{l}\text { the amount of business that } \\
\text { a company does in a period of time }\end{array}$ \\
\hline
\end{tabular}

Source: Definitions adapted from Cambridge Dictionaries Online
(http:/ / dictionary.cambridge.org/)

Table II shows some instances of ESP vocabulary with both general and specific business/financial meanings. Dudley-Evans and St John (1998: 83) posit that teaching ESP is the same as teaching EGP, and that the difference that should be made is between vocabulary for comprehension and production. The teacher's role is to augment learners' awareness of the existence of multivalent lexical items and to help them systematize ESP vocabulary in English.

\section{ESP vocabulary Cognitive Processing}

\section{Cognitive Processing Enhances the Understanding of Metaphor as ESP Vocabulary}

In the acquisition of a second language, understanding words with metaphors requires special cognitive processes. Sometimes key concepts of a lecture might be delivered through metaphor. Low (1988) points out that metaphor is essential in language teaching, as it is the central to the use of a language; structurally, it also pervades large parts of the language system. Dudley-Evans and St John (1998: 84) also claim that, "alternatively, retrieval may be aided with metaphor." For instance, bear and bull describe downturn or boom, respectively, in the stock market. The terms bear and bull correspond to the fact that each animal attacks its opponents. That is, a bull will thrust its horns up into the air, while a bear will swipe down. These actions relate metaphorically to the movement of a market: if the trend was up, it was considered a bull market; if the trend was down, it was a bear market (Investopedia, n.d.). While teaching the ESP vocabulary with the aid of metaphors, learners can comprehend and memorize words more efficiently. 
Littlemore (2001) also states that metaphor intelligence can lead to language learning success. She mentioned metaphors of two categories, "frozen" metaphors and "novel" metaphors. "Frozen metaphors are those that are in common use in the language," while "novel metaphors are ones in which ideas are combined in new or unusual ways" (Littlemore, 2001). For language learners, it takes more effort than for native speakers to comprehend novel metaphors. The main concern of this study is novel metaphors, which can be an essential intelligence in learning ESP vocabulary.

If learners cannot follow the metaphors, they might not understand the key points. Investigations into the ESP of business with metaphors have been conducted, whereby it has been found that cultural differences can also affect metaphor use (Littlemore et al., 2010, as cited in Coxhead, 2013:124). Skorczynska Sznajder (2010, as cited in Coxhead, 2013: 124) concludes from her research findings that corpus evidence, including frequency data, should be considered when selecting teachable metaphorical material for business English instruction. "Approaches to specialist vocabulary instruction through conceptual metaphors are necessary to enhance students' understanding of a discipline" (Skorczynska Sznajder, 2010:40).

\section{ESP Vocabulary Cognitive Processing Approaches}

Oxford (2001) points out that cognitive strategy enable learners to make and strengthen connections between new and already-known information (O'Malley and Chamot 1990; Oxford 1990, 1998, as cited in Oxford 2001). Cognitive strategies' examples are: analyzing, guessing from context, reasoning inductively and deductively, taking systematic notes, and reorganizing information (Oxford, 2001). Oxford (2001) further states that cognitive learning strategies are also known as higher thinking skills, such as synthesizing, analyzing, and reasoning. Cognitive strategies often involve hypothesis testing, such as searching for clues in the surrounding material and in their own background knowledge, and so forth (Oxford, 2001).

Dudley-Evans and St John (1998: 83-87) suggest three ways that vocabulary may be gathered to facilitate cognitive processing, which are here applied for business/financial English vocabulary instruction to the experimental group:

- Situational, semantic and metaphor sets: the retrieval of a vocabulary item from memory is aided by grouping words based on their meanings. This grouping can be according to situational sets: for example, words relating to banking, such as principal, interest rate, mortgage loan, down payment, and so forth, can be taught as a set together, or words related to insurance, such as indemnification, settlement, premium, actuarial, float, severity, claim along with others, and can also be grouped together.

- Collocation and the use of corpora: collocation refers to a group of words that can go together; and from these groupings, lexical sets can be examined (Dudley-Evans and St John, 1998: 84-85). For example, a meeting can be preceded by call, hold, arrange, convene, organize, schedule, or summon (Online Oxford Collocation Dictionary, n.d.).

- Lexical phrases: research into vocabulary learning suggests that learners store vocabulary as chunks of language instead of individual words. These chunks are referred to as lexical phrases (Dudley-Evans and St John, 1998: 86-87). These lexical phrases are useful especially in ESP or for workplace needs. They frequently occur in business correspondence, presentations, and negotiations, etc. Examples are share price and rose substantially. By offering lexical phrases as part of instruction, instructors can boost students' communicative confidence along with improving their ESP sophistication. 
In addition, Davidko's (2011) cognitive approach for teaching business English purposes was also referred to in instructing the experimental group participants in the business or financial English domain. The participants needed to be taught background knowledge of the professional domains in order to acquire business English terminologies. Davidko (2011) points out that "the acquisition of terminology in a foreign language presupposes knowledge of a non-linguistic conceptual structure (conceptual content) and means of verbalization (linguistic content)." Davidko (2011) applied the philosophical notion of qualia to study a term from four cognitive aspects: constitutive, formal, telic, and agentive. He also constructed an abstract "infrastructure" of the subject area to which the words were linked. His aim was to create a "personal construct" - a personal model of knowledge to enhance the learners' information processing capacity in the vocabulary comprehension of a particular field. Furthermore, Blagojevic (1997) mentions that the main cognitive strategies, elaboration (teachers relating new information to learners' prior knowledge) and transfer (applying the acquired knowledge to new situations) can be accompanied by learning strategies for learners to become familiar with new vocabulary. Such cognitive strategies can be useful for non-native speakers when encountering difficulties in identifying specific meanings other than the general ones.

Even though most English learners have acquired language skills for general purposes, onthe-job language usage requires specialized training to learn. For instance, if students plan to engage in the commerce, banking, and finance industries, they need to understand business usage in addition to EGP usage. Coxhead (2013:116) also points out that this is "particularly important if learners are to become fully-fledged members of a particular community."

ESP teaching content turns out to be pivotally important in setting occupationally specific targets and reaching these goals. There is a distinction in the ESP teaching approach between carrier content and real content (Dudley-Evans and St John, 1998:11). Real content includes pedagogical aims, such as language skills or features that the learners need to gain control of. Carrier content involves the ability to deliver the real content (Basturkmen, 2010:59): that is, carrier content relates to actual situations in which the real content is embedded. For instance, when teaching a group of ESP learners who will engage in international trade, teachers might provide a sample Letter of Credit (LC) as carrier content for them to familiarize themselves with the necessary industry vocabulary. Letters of Credit allow importers/buyers to offer secure terms of payment to exporters/sellers in a transaction in which a bank becomes involved (CreditGuru.com, n.d.). They are documents issued by a bank guaranteeing that a seller will receive payment if certain delivery conditions are met. In this lesson, learners may need to learn the usage and meanings of collocations such as conduct a meeting and call a meeting, or of terms involving "bank," such as advising bank, issuing bank, drawee bank and reimbursing bank, or of other terms like beneficiary, bill of lading and airway bill, etc. From the actual LC sample, learners can acquire and practice the target ESP vocabulary effectively in the context of a real situation commonly encountered in a specific industry. Hence, the vocabulary teaching materials, including carrier content and real content, can be explicitly tailored to the learners' needs.

For non-native speakers of a language, it is difficult to comprehend vocabularies in all specific realms. Moreover, Coxhead (2013:116) points out that to develop ESP learners' understanding and use of specialized vocabulary in their subject area fully requires an enormous amount of effort and planning on the part of the teacher. With limited time and resources, ESP instructors should aim to prioritize the particular realms of ESP vocabulary that are most relevant for their learners. 


\section{METHODS}

This study aims to evaluate students' cognitive awareness of ESP vocabulary and conceptual metaphors before and after taking ESP-related courses integrating cognitive processing methods and materials and to further review their effectiveness. The primary variable in this experiment is the effect on the learning of business English/ESP by course instruction that facilitates cognitive processing. As the aforementioned literature review of so many outstanding scholars has demonstrated, their important analyses motivated this study and their ESP vocabulary teaching methodology was applied to teaching business English to the experimental group, including situational, semantic, and metaphor sets; collocation and the use of corpora; and lexical phrases. In addition, the instruction of the experimental group integrated Davidko's (2011) cognitive approach of the qualia structure vocabulary teaching method and personal construct to build a personal model of knowledge, which was offered to the participants.

For instance, when teaching an article on the basic of pricing, the pricing strategies matrixrelated words penetration, skimming, economy and premium are taught together as sets. Further, learners are also taught that in EGP, penetration means the ability to pierce something, and in English for business purposes, penetration pricing aims to establish a long-term dominance in the market. It is advantageous to price products low, preventing competitors from eroding one's position. Skimming in EGP means removing some substance from liquid, e.g., to skim milk, while in business English a skimming price aims at short-term gains rather than long-term dominance. Skimming price aims to maximize profit when there is no competition (Seubert, 2012: 163).

Examples are given to the learners to improve their understanding: skimming price can be sellers setting a high price for a new high-end product (such as a luxurious sports car) or state-of-the-art technology product initially launched on the market without guaranteeing its quality, whereby skimming pricing is needed to cover their initial costs. A penetration pricing strategy can be utilized when a brand or store initially endeavors to enlarge the market by setting a low price to initiate word of mouth and attract customers. The ESP practitioner may try to relate the vocabulary to learners' daily life shopping experiences for them to learn the words by heart. For instance, a great deal on buying donuts from newly opened shops can be inferred as penetration pricing.

Figure 1: Pricing strategies' matrix for ESP vocabulary sets' instruction

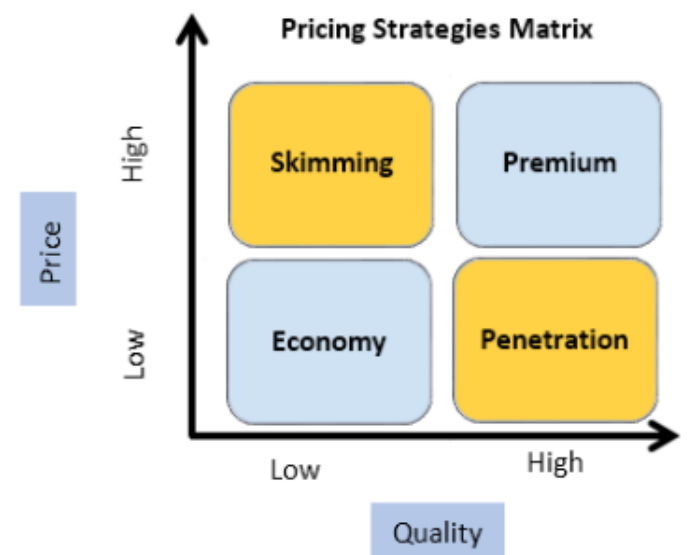

Source: adapted from Seubert (2012: 163) 
Another instruction activity "using mind maps" suggested by Deller and Price (2007) was also applied to activate the business vocabulary for the experimental group. Deller and Price mention that every subject has its own specific key vocabulary. Students learning another subject through English (for example, finance, engineering, or medicine) often do not even know the meanings of these subject words in their mother tongue. Therefore, activities need to be provided to teach the meanings to allow students to learn and effectively memorize them (Deller and Price, 2007: 55). The experimental group was provided with "using mind maps," as suggested by Deller and Price (2007: 56) to categorize new words when learning ESP vocabulary. In the example shown in Figure 2, the instructor provides a list of words and phrases connected to the lesson topic and design them into a mind map. For instance, when giving a lesson introducing interest rates, related words such as benchmark, impetus, basis points, rate hike, reduce interest rate, monetary tightening, quantitative easing (QE), adverse bearing, and soft patch can be taught using mind maps to indicate and elaborate on the words' connections. Students are also encouraged to add relevant words as they arise. This approach can truly help their cognitive processing to further learn and memorize all related words more effectively.

When instructed with these thought-provoking teaching ideas, learners respond well in class. Like all teachers, ESP instructors must appraise how effective their courses have been. This study intends to further ascertain the learning effects of these techniques. It is not possible to evaluate all aspects of ESP learning effects; and as a result, this study mainly focuses on ESP vocabulary learning effects, although the ESP courses offered in the experimental group do not exclusively focus on business vocabulary.

Figure 2: Using mind maps to teach interest rate related financial English vocabulary

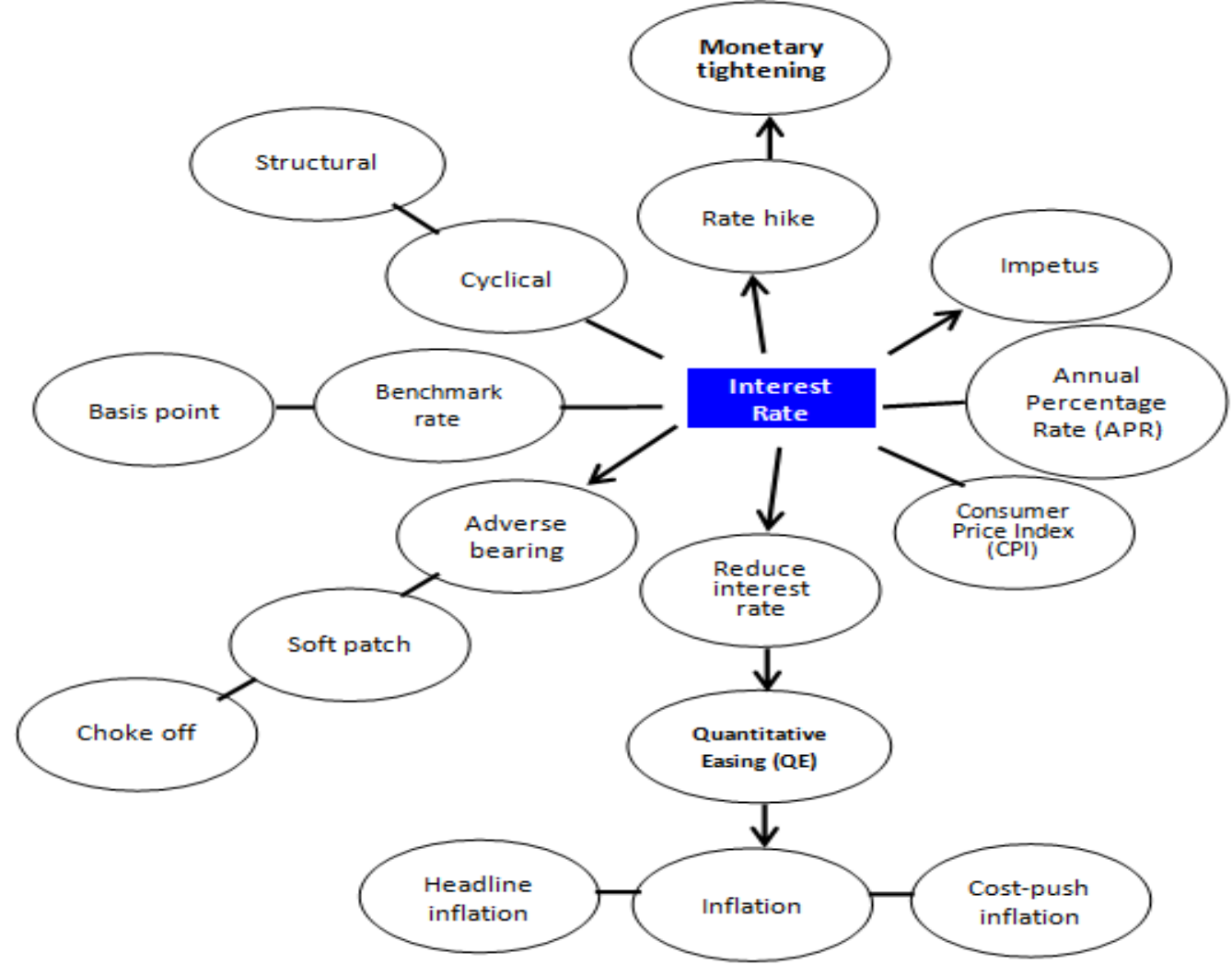




\section{Participants}

The population of this study comprised 197 university students in Taiwan. The subjects were divided into two groups: one control group and one experimental group. All of them came from the same department, with the same level of English education and proficiency. The control group was composed of 103participants who were taking courses with intensified vocabulary learning for general purposes, and who were instructed in conventional ways: that is, when encountering vocabulary, they were taught to look it up in the dictionary and translate the meaning directly for comprehension, without being given further cognitive processing strategies.

Another experimental group comprised 94 participants who were instructed with emphasis placed on the cognitive processing of business and financial English vocabulary, along with contextual comprehension guidance for 2 hours per week for two consecutive semesters of ESP courses. The ESP instructor made dedicated efforts to explain and guide participants in learning business vocabulary using the sea fore mentioned methods during the ESP instruction period. Examinations were given under the condition that the participants had not been notified of them before hand, in order to objectively evaluate the teaching methods.

\section{Questionnaire Design}

The questionnaire contained50multiple-choice questions, which counted as 2 points each (2*50), total a maximum of 100 points. The examination aimed to measure the subjects' ESP vocabulary cognitive awareness before and after taking the ESP courses. The participants were asked to identify and choose the correct meaning of the italicized words in the context. Sample questions are as follows:

- [ ] The chairperson holds a $45 \%$ stake in the company.

[A]a share or a financial involvement in a business

[B] the amount of money that you risk on the result of something, such as a competition

[C] a strong stick or metal bar with a pointed end(Answer: A)

- [ ] They were furious when one of their best managers was poached by another company.

[A] to cook something such as an egg by putting it in boiling water

[B] to persuade someone who works for someone else to come and work for you

[C] to catch and kill animals without permission on someone else's land(Answer: B)

- [ ] The woman leaves her capital untouched in the bank and lives off the interest.

[A] a city which is the center of government of a country or smaller political area

[B] money or property, especially when it is used to start a business or to produce more wealth

[C] a letter of the alphabet in the form of a larger size (Answer: B)

- [ ] The reserve board raised margins from 50 to 60 percent.

[A] the amount by which one thing is different from another

[B] the outer edge of an area

[C] the profit made on a particular product or service (Answer: C)

- [ ] There is a high duty on alcohol.

[A] a tax paid to the government, especially on things that you bring into a country

[B] something that you have to do as your job

[C] or something that you feel is the right thing to do (Answer: A) 
The 50 questions were designed to test the ESP vocabulary proficiency levels of the two groups. Both groups of learners were not prepared for or notified of the exam, meaning that the test captured their actual proficiency under natural conditions. The exam questions did not necessarily contain difficult words, but rather words containing specific meanings in a business or financial field. The aforementioned sample questions were designed for both groups to answer; the testing duration was 40 minutes for both groups.

\section{Results and Data Analysis}

This study intends to compare the ramifications of conventional vocabulary learning results and the ESP vocabulary learning approach by cognitive processing, and to test both groups' proficiency levels in order to determine whether there is a correlation. The study also examines the effectiveness of teaching materials. After participants took the exams, the test papers were collected for grading. All scores were recorded individually for data analysis. While grading the test papers, it was observed that some answers to certain questions might not be evident for non-native participants without ESP training and learning. The score distribution is shown in Figure 3:

Figure 3: Score distribution of two groups of participants Frequency

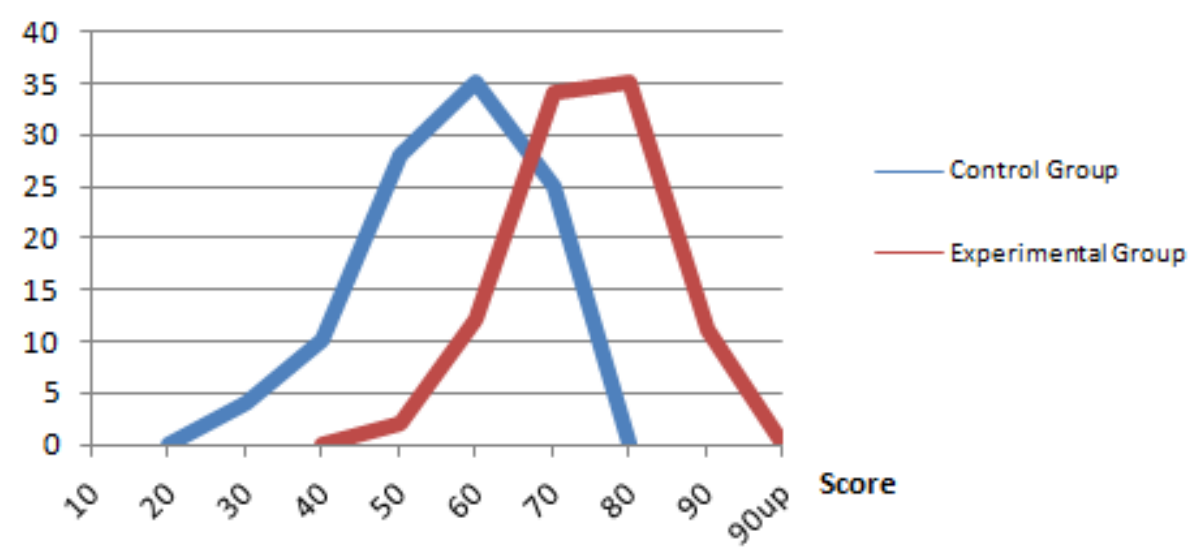

From Figure 3, we observe that the experimental group (which had taken 4 credit hours of ESP courses) performed substantially better than the control group. Furthermore, statistical analyses were conducted by applying Statistical Product and Service Solutions (SPSS) Version 22. Table IV shows the descriptive statistics, including mean, median, mode, standard deviation, variance, and minimum and maximum scores, offering a comprehensive overview of data comparison and allowing us to probe the implications behind the data set.

Table III: Descriptive Statistics

\begin{tabular}{|l|c|c|c|c|c|c|c|c|c|}
\hline & N Valid & Mean & Median & Mode & $\mathrm{SD}^{*}(\sigma)$ & Variance & Minimum & Maximum & Sum \\
\hline $\begin{array}{l}\text { Control } \\
\text { Group }\end{array}$ & 103 & 50.5825 & 52.00 & 56.00 & 11.16939 & 124.755 & 20.00 & 80.00 & 5210.00 \\
\hline $\begin{array}{l}\text { Experimental } \\
\text { Group }\end{array}$ & 94 & 68.2181 & 67.50 & 67.50 & 8.64178 & 74.680 & 42.50 & 82.50 & 6412.50 \\
\hline
\end{tabular}

*Standard Deviation 
Table III shows that in the control group, whose 103 learners had taken EGP courses without ESP courses, the minimum score is 20.0 while the maximum is 80.0 ; the mean score is 50.5825; the median score (the middle score among all scores ranked) is 52.00; the mode, the value appearing most often in this set of data is 56.0; the variance is 124.755; and the SD (the square root of variance as in Figure 4) is 11.16939.

The experimental group of94 learners, who had taken EGP and 4further supplementary credits of EBP courses, obtained a minimum score of 42.5 and a maximum of 82.5; a mean score of 68.2181; a median of 67.50; a mode of 67.50; a variance of 74.680; and an SD of 8.64178 .

Figure 4: Standard deviation equals the square root of variance

$$
\sigma=\sqrt{\operatorname{var}(X)}
$$

The control group's mean of 50.5825 is 17.6356 points less than that of the experimental group at68.2181.This is a $34.87 \%$ ESP vocabulary proficiency difference, one that shows quite considerable improvement after taking ESP courses with cognitive learning strategies.

The control group's variance of 124.755 and experimental group's variance of 74.680 show how far the set of numbers is spread out; the standard deviation (the square root of variance) indicates a similar spread: 11.16939 and 8.64178. The smaller score of the experimental group indicates that all learners' scores are closer to the mean, and less spread out: the learners' levels in this group are more clustered than those in the control group. This demonstrates that with targeted ESP training, a class or group of learners' ESP vocabulary scores can significantly converge. More interestingly, there has been convergence in language enhancement rates. This result shows that the implementation of ESP courses unequivocally advances learners' vocabulary proficiency.

In Table IV, with reference to Laerd Statistics: SPSS Tutorial Guide (2016), from Levene's test for equality of variances, we calculate the significance level to be at $0.002<0.05$, meaning unequal variances and violation of the assumption of homogeneity of variance. Thus, we conclude that equal variances should not be assumed and consider the outcome in the second row, where $\mathrm{t}=-12.453, \mathrm{df}$ (degree of freedom $)=190.025$, sig. (2-tailed) $=0.000$ $\leq 0.05$. From the t-test, we can determine whether there is a statistically significant difference between the means of the two groups. Since the sig. (2-tailed) $=0.000 \leq 0.05$ is far below $5 \%$ and even $<0.01$ (which represents extremely significant results), we can reject the null hypothesis that there is no difference in the variances between the groups and accept the alternative hypothesis that there is a remarkably significant difference in the variances between the two groups. This indicates that the teaching parameters of the experimental group notably enhanced the experimental group's ESP proficiency in business and finance vocabulary through the 4 credit hours of ESP courses, compared with the control group, who have not taken ESP courses thus far in their English instruction. We posit that with more intensive credit hours being offered to learners, their cognitive awareness of ESP vocabulary can be further augmented. 
Table IV: Independent Samples Test

\begin{tabular}{|c|c|c|c|c|c|c|c|c|c|}
\hline \multirow[b]{4}{*}{$\begin{array}{l}\text { Equal variances } \\
\text { assumed }\end{array}$} & \multicolumn{9}{|c|}{$\begin{array}{l}\text { Levene's Test for } \\
\text { Equality of } \\
\text { Variances }\end{array}$} \\
\hline & \multirow[b]{2}{*}{$\mathrm{F}$} & \multirow[b]{2}{*}{ Sig. } & \multirow[b]{2}{*}{$\mathrm{t}$} & \multirow[b]{2}{*}{$\mathrm{df}$} & \multirow[b]{2}{*}{$\begin{array}{l}\text { Sig. } \\
\text { (2-tailed) }\end{array}$} & \multirow[b]{2}{*}{$\begin{array}{l}\text { Mean } \\
\text { Difference }\end{array}$} & \multirow[b]{2}{*}{$\begin{array}{l}\text { Std. Error } \\
\text { Difference }\end{array}$} & \multicolumn{2}{|c|}{$\begin{array}{l}95 \% \text { Confidence Interval } \\
\text { of the Difference }\end{array}$} \\
\hline & & & & & & & & Lower & Upper \\
\hline & 9.962 & .002 & -12.310 & 195 & .000 & -17.63556 & 1.43265 & -20.46103 & -14.81009 \\
\hline $\begin{array}{l}\text { Equal variances } \\
\text { not assumed }\end{array}$ & & & -12.453 & 190.025 & .000 & -17.63556 & 1.41622 & -20.42910 & -14.84202 \\
\hline
\end{tabular}

\section{CONCLUSION}

The lexicon is of pivotal importance in language learning. ESP vocabulary knowledge and buildup require intensive coaching as groundwork and are critical for ESP language enhancement, and therefore professional achievement. Although vocabulary training is only part of the language training necessary to increase expertise, it is never a small-scale field. According to Coxhead (2013: 119), Nelson's (n.d.) study contains two corpora: business English books (approximately 600,000 words), and the Business English Corpus (BEC) (approximately one million words). Nelson also compares business English to general English. His study demonstrates that business English uses an extensive corpus and is a force that needs to be reckoned with: ESP is a prominently and increasingly noted school of thought that creates empirically verifiable results.

We also observe that most of the participants' inaccurate answers result from confusing the general definition and specific purpose definition. Scoring these examination papers and observing participants' mistakes can signal to instructors how to improve teaching to enhance ESP vocabulary skills. As Kennedy and Bolitho (1990: 62) suggest, exercises to practice word relationships would be helpful, as words do not exist in isolation. Many complex relations exist among them, constituting the semantic structure of a language. In order for learners to exploit interrelationships among words, some teaching guidance may be given: synonymy, context clues, and selection from alternatives, and building up sets, collocations, and tasks exercises (Kennedy and Bolitho, 1990: 59-68). With the appropriate training, ESP vocabulary capacity can be notably enhanced.

Moreover, based on this study's clear findings, the insights from the aforementioned ways proposed by ESP scholars in which vocabulary can be gathered to facilitate cognitive processing proved to be substantially effective. Learners' overall performance can be significantly improved with sufficient practice, training hours, and adequate instruction. This observation leads to the optimal ESP course arrangement for departments and college students. In addition to offering professional expertise courses in each department, English for business and financial purposes should be offered to bolster graduates' future career prospects. As Harding (2007:53) states, ensuring that students are learning and using words they will actually need in their specialty is imperative. 


\section{ACKNOWLEDGEMENTS}

This study was carried out with all 197 of the student-participants' cooperation, who conscientiously completed each question of the examination for analysis and valuable teaching reference purposes. Special thanks are due to students who undertook the data collection for this study, namely, Cindy Chung, Emma Wu, Yiting Yu, Alice Ko, and Amy $\mathrm{Wu}$. Thank you all for providing important input into this study.

\section{REFERENCES}

Baker, M. (1988), “Sub-technical vocabulary and the ESP teacher: An analysis of some rhetorical items in medical journal articles", Reading in a Foreign Language, Vol. 4,pp. 91-105.

Basturkmen, H. (2010). Developing courses in English for specific purposes. Basingstoke, UK Palgrave Macmillan.

Blagojevic, S. (1997), Can EGP learning strategies be successfully used in the ESP learning process? ASp. la revue du GERAS, (15-18), pp. 271-283.

Coxhead, A. (2013), "Vocabulary and ESP", in Paltridge B. and Starfield S. (Eds.), The Handbook of English for Specific Purposes, John Wiley \& Sons Chichester, UK, pp. 115-132.

CreditGuru.com (n.d.), "Letter of Credit”, available at:

http:/ / www.creditguru.com/guestarticleLC.htm (accessed 20 September2015).

Davidko, N. (2011). A Cognitive Approach to Teaching English for Special Purposes (ESP). Studies About Languages, (18), 82-89.

Deller S. and Price C. (2007), Teaching Other Subjects through English,Oxford University Press, Oxford.

Dudley-Evans, T. and M. J. St John (1998), Developments in English for Specific Purposes: A MultiDisciplinary Approach, Cambridge University Press, Cambridge.

Harding K. (2007), English for Specific Purposes: Resource Books for Teachers, Oxford University Press, Oxford.

Investopedia (n.d.), "Where did the bull and bear market get their names?", available at: http:/ / www.investopedia.com/ask/answers/129.asp (accessed 2 November 2015).

Kennedy, C. and Bolitho, R. (1990). English for Specific Purposes, Macmillan Publishers Ltd., London and Basingstoke.

Laerd Statistics (2016), “Independent T-Test for Two Samples”, available at: https://statistics.laerd.com/statistical-guides/independent-t-test-statistical-guide.php(accessed 3 November 2015).

Littlemore, J. (2001). Metaphoric intelligence and foreign language learning. Humanising LanguageTeaching Magazine, 3(2).

Low, G. D. (1988),“On teaching metaphor”, Applied Linguistics, Vol. 9, pp. 125-147.

Nation,I.S.P. (1990), Teaching and Learning Vocabulary, Heinle \& Heinle, Boston, Massachusetts.

Nelson, M. (n.d.), “Mike Nelson's Business English Lexis Site”, available at: http:/ / users.utu.fi/micnel/BEC/keywordsindex.htm (accessed 12 October 2015).

O'Malley, J.M. and Chamot, A. U. (1990), Learning Strategies in Second Language Acquisition, Cambridge University Press, Cambridge.

Online Oxford Collocation Dictionary (n.d.), "Meeting", available at: http:/ / oxforddictionary.so8848.com/search?word=meeting (accessed 30 October 2015).

Oxford, R.L. (2001), "Language learning strategies", in Carter, R. and Nunan, D. (Eds.), Teaching English to Speakers of Other Languages,Cambridge University Press, Cambridge, pp.166-172. 
Seubert, C.M.R. (2012), Absolute Financial English: All the Basics You Need to Know. Cosmos Culture Ltd., Taipei.

Skorczynska Sznajder, H. (2010),"A corpus-based evaluation of metaphors in a Business Englishtextbook", English for Specific Purposes, Vol. 29 No. 1,pp. 30-42.

$--0-$ 